\title{
Lung Cancer in Young Patients Under the Age of Thirty-five: Single Center Experience
}

\section{Otuzbeş Yaş Altı Genç Hastalarda Akciğer Kanseri: Tek Merkez Deneyimi}

\author{
Mehmet Özen $^{1}$, Funda Pepedil ${ }^{1}$, Mustafa Cengiz ${ }^{1}$, Sadettin Kılıçkap², Sercan Aksoy ${ }^{2}$, Alev Türker ${ }^{2}$, Ayşe \\ $\mathrm{Kars}^{2}$
}

${ }^{1}$ Hacettepe Üniversitesi Tıp Fakültesi, İç Hastalıkları Ana Bilim Dalı, Ankara, Türkiye

${ }^{2}$ Hacettepe Üniversitesi Tıp Fakültesi, Medikal Onkoloji Bilim Dalı, Ankara, Türkiye

\section{ÖZET}

Amaç: Akciğer kanseri dünyada en sık görülen kanserdir. Nadiren 35 yaş ve altında görülür. Hastaların tanı anındaki ortanca yaşı 71 'dir.

Yöntemler: Enstitümüzde tanı anında 35 yaşında veya daha genç olan hastaları retrospektif olarak inceledik. Bulgular: 2001 ile 2008 yılları arasında yaşları 19 ile 35 arasında değişen 17 hasta tanımladık. Ortanca yaş 30 (aralık, 19-35) ve ortanca takip süresi 11 aydı (aralık, 1-74 ay). Erkek ve kadınların sayıları sırasıyla 8 (47\%) ve $9(53 \%)$ idi. Tanı anında hastaların \%82'si $(\mathrm{n}=14)$ evre IV, \%18'i ise evre III hastalık vardı. Hastaların $\% 47$ 'sinde beyin metastazı mevcuttu. Çalışma grubunda en sık görülen histolojik tip adenokarsinom iken (\%56), küçük hücreli akciğer kanseri \%6 oranında bulundu. Sadece bir olgunun öyküsünde sigara kullanımı risk faktörü olarak yer alıyordu. Tüm hastaların tedavisinde platin bazlı kemoterapi yer almakta idi. Sadece bir hastanın kendisinde meme kanseri öyküsü vardı. Sadece bir hastanın ailesinde kanser öyküsü vardı ve bu da kolon kanseriydi. Toplam 14 hasta akciğer kanseri nedeni ile kaybedildi. Sağkalım oranları hastalarımızda düşüktü. Bunun yanında cinsiyet ve evre de sağkalım oranlarını etkilemedi.

Sonuç: Akciğer kanseri gençlerde nadir görülen bir hastalıktır. Gençlerde teşhis konulduğunda ise metastatik olmaya eğilimlidir. En sık metastaz bölgesi beyindir. Bizim hastalarımızda küçük hücreli akciğer kanseri nadir olup en sık tip adenokarsinomdur. Sigara kullanımı, ailede veya kendisinde kanser hikayesi genç hastalarda akciğer kanseri için önemli risk faktörü olarak görünmemektedir. Hastalığın etiyolojisi olasılıkla yaşlı hastalardan farklıdır.

Anahtar Kelimeler: Akciğer kanseri; Genç

\begin{abstract}
Objective: Lung cancer is the most common cancer in the world. It is rarely seen under the age of 35 . The median age of patients at diagnosis is 71 .

Methods: In our institute we have retrospectively evaluated patients who are 35 years old or younger at the time of diagnosis.

Results: We have defined 17 patients whose ages were ranging between 19 and 35, from 2001 to 2008. Median age was 30 (range, 19-35) and median follow up time was 11 months (range: 1-74 months). The number of men and women was $8(47 \%)$ and $9(53 \%)$, respectively. At diagnosis, $14(82 \%)$ patients had stage IV, $3(18 \%)$ patients had stage III disease. Brain metastases were present in $47 \%$ of patients. In our study adenocarcinoma was the most common (56\%) histological subtype and small cell lung cancer was rare (6\%). Only one patient had smoking history as a risk factor. All patients received platinum based chemotherapy. Only one patient had personal cancer history and it was breast cancer. Only one patient had family history for cancer and it was colon cancer. A total of 14 patients died due to lung cancer. Survival rate in patients were low. Beside, gender or stage did not affect survival rates.

Conclusion: Lung cancer is rare in young people. When it is seen in young patients, it tends to be metastatic and the most common site of metastases is brain. In our patients the most common histology was adenocarcinoma and small cell lung cancer was rare. Smoking history, family history or personal cancer history did not appear to be important risk factors for lung cancer in young people. The etiology of disease is probably different from elderly people.
\end{abstract}

Key words: Lung cancer, Young 


\section{Giriş}

Akciğer kanseri tüm dünyada en s1k görülen kanser olup hem erkeklerde hem de kadınlarda kanser ilişkili mortalitenin en önemli sebebidir $(1,2)$. Hastalık gelişiminde pek çok çevresel faktör rol alır, ancak en önemli risk faktörü sigaradır. Sigara, tüm akciğer kanserlerinin \%90'nından sorumludur (3). Bugün için genetik faktörlerin patogenezdeki rolü net olmamakla birlikte iyi tanımlanmış bir ailesel risk söz konusudur.

Akciğer kanseri çoğunlukla orta ve ileri yaş grubunun hastalığıdır. Tanı sırasında hastaların ortanca yaşı 71'dir (4). Elci ve ark. tarafindan Türkiye'deki genç erkeklerde yapılan bir çalışmada olguların ortalama tanı yaş1 53 olarak bildirilmiştir (5). Bununla birlikte tüm akciğer kanserlerinin ancak \%1 kadarı 40 yaşın altındadır ve 35 yaşından önce çok nadir görülmektedir (6). Nadir görülmesi nedeni ile de genç erişkin hastalarda akciğer kanseri ile ilgili literatür verileri oldukça kısıtlıdır. Bu yaş grubu için risk faktörleri ve hastalık seyri bilinmemektedir. Mevcut bilgiler 1şığında bu çalışmada kliniğimizde primer akciğer kanseri teşhisi alan 35 yaş ve altındaki olguların retrospektif olarak incelenmesi amaçlanmıştır.

\section{Gereç ve Yöntem}

Ocak 2001 ile Aralık 2008 tarihleri arasında hastanemizde akciğer kanseri tanısı almış olan hastalar incelenerek, tanı esnasında 35 yaşında veya daha küçük olan 17 hasta olduğu saptanmıştır. $\mathrm{Bu} 17$ hasta retrospektif olarak incelenmiştir. Gerekli veriler hasta dosyalarından, bilgisayar kayıtlarından ve gerektiğinde hastayı takip eden doktordan alınmıştır. Hastaların sağkalım verisinin çıkarılabilmesi için nüfus kayıtlarından yararlanılmış, tüm hastaların hastane kayitlarındaki telefon numaralarını kullanılarak kendisi veya yakınları aranmış ve yaş, ölüm tarihi gibi olası yanlış veriler ortadan kaldırılarak sonuçlar doğrulanmıştır. Numerik veriler ortanca (aralık) olarak verilmiştir. İstatistiksel analiz kategorik değişkenler için Ki-kare, parametrik olmayan değişkenler için Mann Whitney U testi kullanılarak yapılmıştır.

Toplam sağkalım (TS) tanı anından itibaren hesaplanmıştır. TS hesaplanırken Kaplan-Meier testi kullanılmış ve sonuçlar logRank testi kullanılarak kıyaslanmıştır. Tüm sonuçlar için $\mathrm{p}<0,05$ anlamlı kabul edilmiştir. İstatistiksel analiz SPSS 16.0 kullanılarak yapılmıştır.

\section{Sonuçlar}

Sekiz erkek, 9 kadın toplam 17 hastanın ortanca yaşı 30 (aralık, 19-35 yaş) idi. Hastaların ortanca takip süresi ise 11 aydı (aralık, 1-74 ay). Hastaların \%82'si başvuru anında evre 4 hastalığa sahipti. Geri kalan üç hasta ise evre 3 hastalığa sahipti. Beyin metastazı sekiz hastada (\%47) gözlendi (Tablo $1)$.

En s1k başvuru semptomu öksürük (\%28) olmakla birlikte nefes darlı̆̆1, senkop, baş dönmesi, baş ağrısı, yan ağrısı ve yaygın kemik ağrısı başvuru semptomu olarak görülmekte idi. Sadece bir olgunun öyküsünde sigara kullanımı risk faktörü olarak yer alıyordu. Histolojik olarak değerlendirildiğinde küçük hücreli akciğer kanserinin nadir olduğu, buna karşın adenokarsinomun sık olduğu gözlendi. Çalışma grubunda en s1k görülen histolojik tip adenokarsinom iken (\%56), küçük hücreli akciğer kanseri \%6 oranında bulundu. Tüm hastalara platin bazlı kemoterapi verildi. Bir hastanın hikayesinde meme kanseri nedeniyle kemoterapi aldığı görüldü. Sadece bir hastanın ailesinde kanser öyküsü olup, o da kolon kanseriydi. Cerrahi tedavi uygulanan hasta sayısı üç iken tüm hastaların tedavisinde platin bazlı kemoterapi yer almakta idi. Bu süreçte toplam 14 hasta akciğer kanseri nedeni ile kaybedildi. Geri kalan üç hasta ise değerlendirme esnasında hayattaydı (Tablo 1). 
Tablo 1. Demografik veriler

\begin{tabular}{|l|c|}
\hline & $\mathrm{n}=17, \%$ \\
\hline Yaş & $11(65)$ \\
\hline 30 yaş ve altı & $6(35)$ \\
\hline $31-35$ yaş & \\
\hline Cinsiyet & $9(53)$ \\
\hline Kadın & $8(47)$ \\
\hline Erkek & \\
\hline Sigara öyküsü & $1(6)$ \\
\hline Var & $16(94)$ \\
\hline Yok & \\
\hline Ailede kanser öyküsü & $1(6)$ \\
\hline Var & $16(94)$ \\
\hline Yok & \\
\hline Hastada kanser öyküsü & $1(6)$ \\
\hline Var & $16(94)$ \\
\hline Yok & \\
\hline Histolojik tip & $1(6)$ \\
\hline Küçük hücreli & $16(94)$ \\
\hline Küçük hücreli diş1 & $3(18)$ \\
\hline Evre & $14(82)$ \\
\hline III & \\
\hline IV & \\
\hline
\end{tabular}

Hastalar mortalite oranı açısından cinsiyet, evre, beyin metastazı varlığ ve yaşlarına göre kıyaslandı ancak mortalite oranını bu değişkenlerin etkilemediği gözlendi (p>0.05). Yapılan sağkalım analizinde de bu değişkenlerin toplam sağkalım üzerinde etkisi gösterilemedi $(\mathrm{p}>0.05)$. Tüm hastalar için ortanca sağkalım 10 ay (aralık, 5.5-14.5 ay) olarak hesaplandı (Şekil 1). Evre 3 hastalar için ortanca toplam sağkalım ortanca 12.4 ay iken, evre 4 hastalar için 9.4 aydı ( $>0.05$ ) (Şekil 2). Kadın hastalar için ortanca toplam sağkalım 12.9 ay iken erken hastalar için 9.1 aydı (Şekil $3)$.

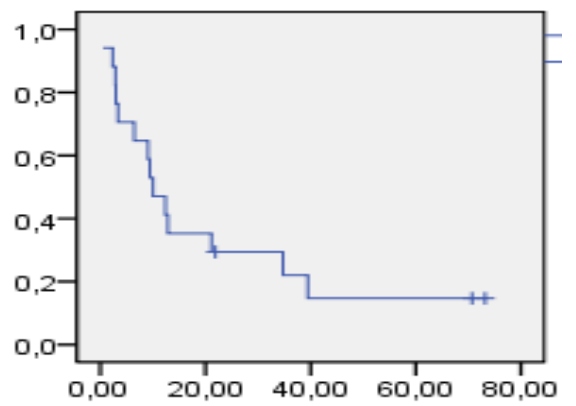

Şekil 1: Tüm hastalarda toplam sağkalım (ay)

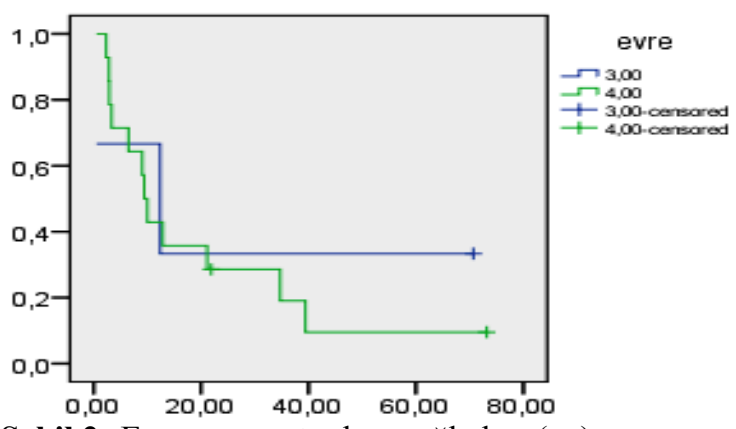

Şekil 2: Evreye göre toplam sağkalım (ay)

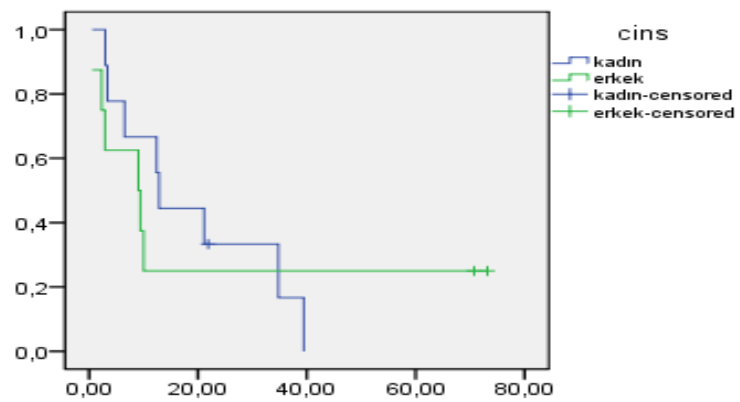

Şekil 3: Cinsiyete göre toplam sağkalım (ay)

\section{Tartışma}

Akciğer kanserli olguların büyük çoğunluğu ileri veya orta yaşlı hastalardır. Tüm akciğer kanserlerinin \%1'i 40 yaş altında gözlenmektedir (6). Literatürde genç hastalarda akciğer kanserini değerlendiren az sayıda çalışma vardır ve her birinde farklı yaş sinırları belirlenmiştir ( 40 yaş, 45 yaş ve 50 yaş altı) (512). Bununla birlikte çalışmamızda üst sınır olan 35 yaş ve altındaki hastalar için veriler oldukça kısıtlıdır.

Gençlerde en sik rastlanan histolojik tip adenokarsinom olarak bildirilmiştir (11, 12). Öte yandan, Elci ve ark. tarafindan yayınlanmış bir araştırmada Türkiye'de 45 yaş ve altında ileri yaşa oranla küçük hücreli akciğer kanseri riskinin arttığ Bizim çalışmamızda olguların \%53'ünde adenokarsinom olduğu görülmüştür. Küçük hücreli akciğer kanseri ise çok nadir olup sadece bir vakada görülmüsstür.

Genç hastaların klinik özellikleri ve tedavi sonrası prognozlarının değerlendirildiği epidemiyolojik çalışmalarda 50 yaşın altındaki hastalarda erken evre hastalık söz konusu olduğunda küçük oranda bir TS avantaj1 olduğu bulunmuştur (6,13). Ancak, tanı sirasinda lokal evrede olan hasta oranı sadece \%20'nin altında olarak bildirilmiştir. Benzer şekilde bizim olgularımızda da tanı sırasında $\% 83$ oranında metastatik hastalık söz Address for CorrespondenceDr. Mehmet Özen, Hacettepe Üniversitesi Tıp Fakültesi, İç hastalıkları Bilim Dalı, 06100 Sıhhiye 06590 Ankara - Türkiye Available at: www.actaoncologicaturcica.com 
konusudur. Beyin metastazı akciğer kanseri seyrinde sik görülse de genç yaşta gözlenen beyin metastazı olguları oldukça nadir olup kötü seyirlidir (14). Bizim çalışmamı genç akciğer kanserli olgularda bu kadar çok sayıda beyin metastazının gözlendiği ikinci çalışma olup bu açıdan yeni yapılacak çalışmalara ihtiyaç vardır. Genç yaşta gözlenen akciğer kanserlerinde sigaranın etkisi oldukça sınırlı olup çevresel etkenler veya aile hikayesinin önemli olabileceğinden bahsedilmektedir $(15,16)$. Bizim çalıșmamızda hasta sayısı sınırlı da olsa sonuçlar bu faktörlerin etkin olmayabileceğini düşündürmektedir.

Tüm bunlarla birlikte muhtemelen çalışmadaki hasta sayısının azlığı ve hastaların k1sa yaşam süresine sahip olması nedeniyle evrelere göre ve cinsiyete göre TS açısından fark bulunamamıştır. Hasta sayısının azlığı çalışmanın bir dezavantaj1 olarak görülmektedir. Yine hasta sayısının azlığı nedeniyle sigara içmemiş kadın hastaların bu yaş grubundaki sağkalımı ile ilgili de bilgiye ulaşılamamıştır. Yalnız 35 yaş altı genç akciğer kanserli hastaların farklı bir grup olduğu, bu grupta klasik akciğer kanserinde gözlenen erkek cinsiyet dominantlığının gözlenmediği ve sigara ile arasındaki organik bağın klasik akciğer kanseri kadar olmayabileceği görülmüştür.

Sonuç olarak genç yaşlarda gözlenen akciğer kanseri metastatik olmaya meyilli olup, en sik gözlenen metastaz bölgesi beyindir. $\mathrm{Bu}$ hastaların s1k gözlenen alt tipi adenokarsinom olup, küçük hücreli akciğer kanseri çok nadirdir. Hastalarımız daha çok kadın cinsiyette, sigara içmemiş, adenokarsinomlu olgular olup kemoterapiye rağmen agresif seyretmiştir. Bu hastalarda sigara içimi, kişide veya ailede kanser öyküsü önemli nedenler olarak görülmemektedir. Olasılıkla hastalığın etiyolojisi yaşlı hastalarda gözlenen akciğer kanserinden farklidır ve bu grup hastaların ayrı değerlendirilmesi gerekebilir.

Çıkar Çatışması: Yok

\section{Kaynaklar}

1. Jemal A, Bray F, Center MM, Ferlay J, Ward E, Forman D. Global cancer statistics. CA Cancer J Clin 2011;61:69-90

2. Jemal A, Siegel R, Xu J, Ward E. Cancer statistics, 2010. CA Cancer J Clin 2010;60:277-300

3. Alberg AJ, Samet JM. Epidemiology of lung cancer.Chest 2003;(1 Suppl):21S-49S

4. Dela Cruz CS, Tanoue LT, Matthay RA. Lung cancer: epidemiology, etiology, and prevention. Clin Chest Med 2011;32:605-44

5. Elci OC, Akpinar-Elci M. The trend of small cell lung cancer among young men. Lung Cancer 2007:57:34-6

6. Subramanian J, Morgensztern D, Goodgame B, et al. Distinctive characteristics of non-small cell lung cancer (NSCLC) in the young: a surveillance, epidemiology, and end results (SEER) analysis. J Thorac Oncol 2010;5:23-8

7. Jiang W, Kang Y, Shi GY,et al. Comparisons of multiple characteristics between young and old lung cancer patients. Chin Med J (Engl) 2012;125:72-80

8. Veness MJ, Delaney G, Berry M. Lung cancer in patients aged 50 years and younger: clinical characteristics, treatment details and outcome. Australas Radiol 1999;43:328-33

9. Prasad R, Verma SK; Sanjay. Comparison between young and old patients with bronchogenic carcinoma. J Cancer Res Ther 2009;5:31-5

10. Awadh-Behbehani N, Al-Humood K, Ayed A, Memon A, Ali A. Comparison between young and old patients with bronchogenic carcinoma. Acta Oncol 2000;39:995-9

11. DeCaro L, Benfield JR. Lung cancer in young persons. J Thorac Cardiovasc Surg 1982;83:372-6

12. Shimono T, Hayashi T, Kimura M, et al. Surgical treatment of primary lung cancer in patients less than 40 years of age. J Clin Oncol 1994;12:981-5

13. Ramalingam S, Pawlish K, Gadgeel S, Demers R, Kalemkerian GP. Lung cancer in young patients: analysis of a Surveillance, Epidemiology, and End Results database. J Clin Oncol 1998;16:651-7

14. Nieder C, Thamm R, Astner ST, Molls M. Disease presentation and treatment outcome in very young patients with brain metastases from lung cancer. Onkologie 2008;31:305-8

15. Wakelee HA, Chang ET, Gomez SL, et al. Lung cancer incidence in never smokers. J Clin Oncol 2007;25:472

16. Brenner DR, Hung RJ, Tsao MS, et al. Lung cancer risk in never-smokers: a population-based casecontrol study of epidemiologic risk factors. BMC Cancer 2010;10:285 